\section{Population Pressure Diluted}

THE British government's population panel, under the chairmanship of Professor C. R. Ross of the Central Policy Review Staff, has produced an exhaustive report of the possible effects of different levels of population in Britain in the next hundred years (Report of the Population Panel, HMSO, Cmnd. 5258, £0.90). It is at once clear that the panel's recommendations are well founded and that its approach to assessing whether or not Britain should have a population policy can be commended. In particular, the presentation to government departments of three alternative models of the British population for fifteen and forty years ahead when asking these departments for their views on the relevance of population trends was a wise move, the success of which will benefit other inquirers of these departments.

But what of the recommendations? The panel suggests that the government should not in future regard the level and rate of increase of the population with indifference but also, quite properly, it does not see the need for fiscal policy to influence the size of families in the foreseeable future. But the panel is loud in its warning that the government should not have a population policy that sets a definite limit for the British population at some time in the future. It is proper that the panel has steered clear of defining an optimum population, for there are no accurate ways of calculating this figure in terms of economic benefits to the country, but suggestions which have been made that the optimum British population should be 30 million, based presumably on the fact that only enough food is produced within Britain to feed this number, are quite sensibly dismissed by the panel on the grounds that "to frame policy in terms of 'targets' which take no account of the built-in momentum of the demographic process or the uncertainties about the extent to which population growth can be influenced by policy is neither sensible nor realistic".

It now seems that the population of Britain will increase from its present value of about 55 million to 64 million sometime during the first decade of the next century. It is brave of the panel, in view of the concern that has been expressed about the size of the British population, to come out and say that given a not too unstable world situation, Britain should be able to find means of accommodating any likely increase in population over the next forty years. There will also be little disagreement with the panel's view that Britain would be better off with a stationary population than with an expanding one, although such a situation is unlikely to occur in the near future. For those that take apparent delight in predicting that catastrophe of one sort or another is around the corner, the report brings little comfort. Professor Ross is quite clear in his recommendation that provided the rate of increase of population does not change suddenly the prospects for the next thirty or forty years are such that no drastic action is required.

Much of the uncertainty and confusion which has arisen in the past about the implications of population growth has been caused by a palpable shortage of information. Why do fertility rates change with no apparent rhyme or reason, the increase in Britain in the early 1960s in particular? Similarly, what are the factors which affect mortality, especially in children? To what extent do emigration and immigration affect population estimates? And with Britain now firmly entrenched within the European Economic Community the question has to be asked whether British people are going to move to Europe in increasing numbers or whether the Europeans will find the grass greener in Britain than in their homelands? The Population Panel has been equal to the challenge and the recommendation that a centre be set up for population studies is to be welcomed as indeed is the suggestion that it should be built at a university and that it should be closely connected to the economics, social sciences, biology and medical departments of that university.

Population, according to the panel, should become the responsibility of a senior non-departmental minister and a small group on population matters should be set up within the Cabinet Office together with an interdepartmental committee to coordinate all work on population. It is also recommended that the Office of Population Censuses and Surveys should also be expanded and strengthened, chiefly in order to analyse demographic data but also to commission research on population matters. A Minister for Population, as is admitted in the report, could not be effective without having at his fingertips a great deal more information on population than is now available. This, combined with the panel's assurance that the expected increase in the British population in the next thirty or forty years is not likely to cause difficulties, makes the need for a minister less immediate than the need for more research in demography.

\section{Tunnelling for Trouble}

THE British and French governments, having apparently learned nothing from their ill-starred Concorde project, seem bent on spanning the English Channel with a tunnel first proposed in the 1850 s and which is unlikely now to be an economic proposition. In a memorandum on the subject published last week (The Channel Tunnel Project, Cmnd 5256, HMSO, £0.365), the Minister for Transport Industries, Mr John Peyton, says, to be sure, that "the project will only be undertaken if it is shown by the current technical, economic and financial studies to be a sound business proposition" but he has also spelled out a timetable for making a decision which is exceedingly tight. The document says that a treaty between France and the United Kingdom will be needed by July 31 this year and that preliminary works on the tunnel would begin this autumn with the prospect of a final agreement on the financing of the tunnel itself being signed early in 1975, just two years from now. There is no objection to the way in which the project has several intermediate decision points, but it is seriously to be questioned 